DOI: 10.35784/IAPGOS.728

\title{
DESIGN, CONSTRUCTION AND AUTOMATIC CONTROL SYSTEM OF SINGLE-STAGE SIX-BED ADSORPTION HEAT PUMP
}

\author{
Katarzyna Zwarycz-Makles ${ }^{1}$, Sławomir Jaszczak ${ }^{2}$ \\ ${ }^{1}$ West Pomeranian University of Technology Szczecin, Department of Heating, Ventilation and Heat Engineering, Szczecin, Poland, ${ }^{2}$ West Pomeranian University \\ of Technology Szczecin, Department of Methods of Artificial Intelligence \& Applied Mathematics, Szczecin, Poland
}

\begin{abstract}
The construction and automatic control of single-stage six-bed adsorption heat pump for heating and cooling purposes is discussed. The presented device is design to simulate operating conditions as well as temperature and uptake changes in the adsorbers/de sorbers and consequently to describe the performance of the six-bed adsorption heat pump. The authors focus on advanced operation and strategy of multi-bed heat pump adsorber/desorber performance configuration. Through the use of a sequential system of sorption columns operation, the continuous character of the gained power of device in a wide range is obtained. It is possible as a result of using in the device the quantitative control of the pump by switching sequentially columns (sequential control), quality control by changing the temperature of heating/cooling water flowing in series or parallel through sorption columns and by changing the time parameter of sorption process (adsorption/desorption time) of the bed.
\end{abstract}

Keywords: heat pump, adsorption, automatic control

\section{PROJEKT, BUDOWA I SYSTEM AUTOMATYCZNEJ REGULACJI JEDNOSTOPNIOWEJ SZEŚCIOKOMOROWEJ ADSORPCYJNEJ POMPY CIEPLA}

Streszczenie. $W$ artykule przedstawiono projekt budowy i automatycznej regulacji jednostopniowej sześciokomorowej adsorpcyjnej pompy ciepła zastosowanej do uzyskania ciepła $i$ chłodu. Omawiane urządzenie zaprojektowano $w$ celu oceny parametrów pracy oraz zmian temperatury $i$ stężenia $w$ adsorberze/desorberze a $w$ konsekwencji $w$ celu określenia efektywności sześciokomorowej adsorpcyjnej pompy ciepła. Autorzy skoncentrowali się na możliwości zaawansowanej regulacji pracy i efektywności wielokomorowego urzadzenia. Poprzez zastosowanie sekwencyjnego układu komór sorpcyjnych otrzymano ciagly charakter uzyskiwanej mocy w szerokim zakresie. Jest to możliwe w wyniku zastosowania w urządzeniu regulacji ilościowej mocy pompy poprzez załączanie kolejnych segmentów (regulacja sekwencyjne), regulację jakościowa poprzez zmianę temperatur wody grzewczej/chłodzącej przepływającej szeregowo/równolegle przez kolumny sorpcyjne oraz przez zmianę parametru czasu pracy (czasu adsorpcji/desorpcji) kolumny.

Słowa kluczowe: pompa ciepła, adsorpcja, automatyczna regulacja

\section{Introduction}

Contemporary directions of technical development are inextricably linked to the rational management of natural resources and the protection of the natural environment. In the field of heat pumps, the compressor ones are still the most popular. However, it is not insignificant that electric energy is required for their work, the production of which causes increased emission of greenhouse gases during the conversion of energy accumulated in natural fuels into electricity. For this reason, it is important to limit the consumption of fossil fuels and that is why the sorption technologies (absorption and adsorption), which directly use heat, especially of low temperature sources to drive the heat pumps, are becoming more and more important $[8,9,13$, $15,20]$.

The adsorption methods are widely used in chemical industry, environmental protection and other fields, for separation and purification of gases and liquids [2, 6, 10]. During the past two decades, this phenomenon was exploited to produce cooling and heating $[11,17,19]$. With the increasing prices of electricity, the advantage of sorption pumps is the use of thermo-chemical compression, instead of mechanical compression, therefore instead of electricity, the adsorption heat pump drives heat $[4,5,7,12]$. Recently a large amount of research was done on various types of adsorption heat pumps, as an alternative to vapour compression systems $[1,14,16]$.

Adsorption devices can be used in two main ways, giving a wide range of user experience. The first application, becoming more and more important, is the use for cold production, the second - the use of adsorption systems for heat production $[3,18]$.

In relation to adsorption heat pumps, the requirement of competitiveness in technical and economic terms is faced with the classical technology of heat production in compressor systems. However, the problems of the appropriate construction of adsorbers and desorbers, so that they provide favourable conditions for heat and mass exchange inhibit the development and installation of these units in heating and cooling systems, because they do not achieve satisfactory values of the COP
(Coefficient of Performance) as well as the coefficient SCP (Specific Cooling Power) in relation to the high price of the unit.

In order to increase the efficiency of utilization of low temperature heat source, to increase efficiency of the adsorption heat pump, modification of the basic single-stage two-bed construction of the adsorption heat pump to the multi-bed construction is proposed [21, 22]. In this paper advanced operation and strategy of single-stage six-bed heat pump adsorbers/desorbers performance is presented. The presented device is design to simulate operating conditions as well as temperature and uptake changes in the adsorbers/desorbers and consequently to describe the performance of the six-bed adsorption heat pump.

\section{Design and construction of single-stage six-bed adsorption heat pump}

Heat pump under consideration is designed as multifunctional device which could be operated in: serial-serial, serial-parallel, parallel-parallel mode of heating/cooling water flow.

Technical project of the six-bed adsorption heat pump with serial-serial flow of heating/cooling medium and its automatic control is presented. The heating and cooling power of device can be controlled: quantitative (control in steps), qualitative and working time of bed.

\subsection{Construction and technical parameters}

Multi-bed heat pump consists of the same basic elements as the conventional two-bed heat pump (evaporator, adsorber/desorber columns and condenser) but involve the sequential application of the sorption columns therefore is equipped with additional control valve blocks (the so-called multivalve). Adsorption heat pump, presented in the Fig. 1, operates with silica gel as adsorbent and water adsorbate. There are two basic circuits: closed internal circulation - in which the adsorbate (refrigerant vapour - water vapour) circulates, and an open external circuit as the heat transport outside the device (heating/cooling water). 
(1) CONDENSER

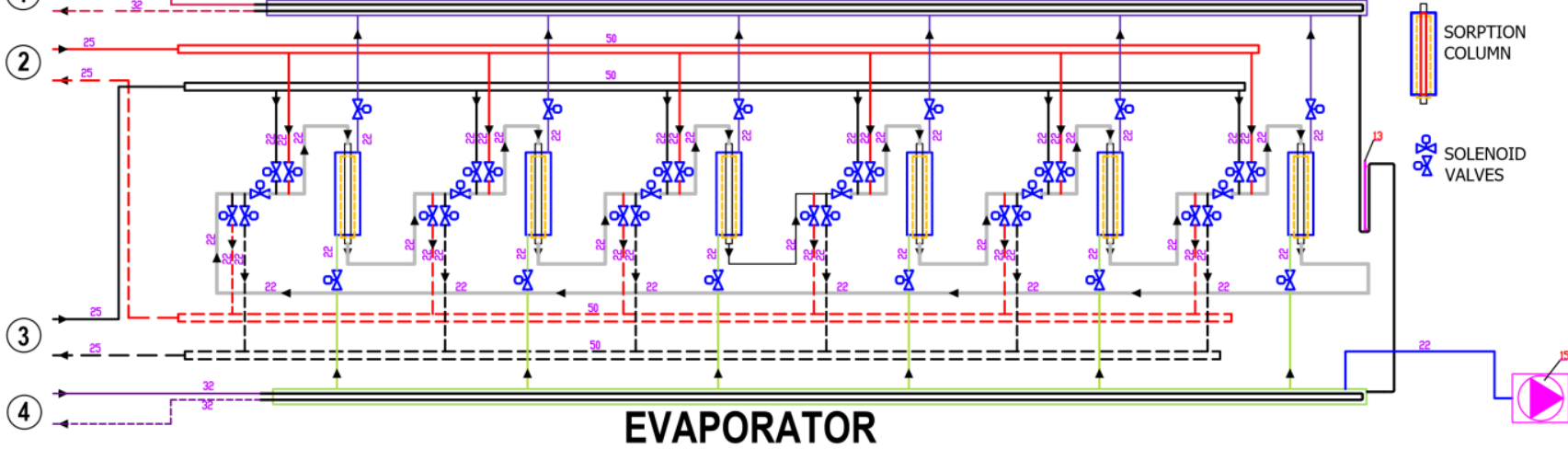

EVAPORATOR

(1) COOLING WATER
$35^{\circ} \mathrm{C}-50^{\circ} \mathrm{C}$
(3) COOLING WATER

(3) $30^{\circ} \mathrm{C}-45^{\circ} \mathrm{C}$
(4) CHILLED WATER
$5^{\circ} \mathrm{C}-25^{\circ} \mathrm{C}$

Fig. 1. Scheme of the six-bed adsorption heat pump with serial heating/cooling water flow and sequential application of the sorption columns

\begin{tabular}{|c|c|c|c|c|c|c|c|c|c|c|}
\hline \multirow{9}{*}{$\begin{array}{l}\text { column } 1 \\
\text { column } 2 \\
\text { column } 3 \\
\text { column } 4 \\
\text { column } 5 \\
\text { column } 6\end{array}$} & \multicolumn{10}{|c|}{ time } \\
\hline & ads & des & des & des & ads & ads & ads & des & des & \multirow{7}{*}{$\begin{array}{l}\text { switching direction of columns } \\
\text { in operating phases }\end{array}$} \\
\hline & ads & ads & des & des & des & ads & ads & ads & des & \\
\hline & ads & ads & ads & des & des & des & ads & ads & ads & \\
\hline & des & ads & ads & ads & des & des & des & ads & ads & \\
\hline & des & des & ads & ads & ads & des & des & des & ads & \\
\hline & des & des & des & ads & ads & ads & des & des & des & \\
\hline & faze 0 & faze 1 & faze 2 & faze 3 & faze 4 & faze 5 & faze 0 & faze 1 & faze 2 & \\
\hline & \multicolumn{6}{|c|}{ cycle 0} & \multicolumn{4}{|c|}{ cycle 1} \\
\hline
\end{tabular}

Fig. 2. Operating phases of the sorption beds of the six-bed adsorption heat pump in the serial-serial system ( 3 columns for adsorption / 3 columns for desorption)

The adsorption heat pump under consideration consists of an evaporator, six adsorber/desorber columns and a condenser. The sorption column contains tube with deposited adsorbent (silica gel)

The sorption column performs dual function: it works as an adsorber when cooled by cooling water and as a desorber when heated by hot driving water from outside. The adsorber/desorber is connected to the evaporator on one side while plugged in to the condenser on the other side with control valves. During the adsorption process, the adsorbate (refrigerant vapour) enters the adsorber after leaving the evaporator. When cooling water is switched to hot water, the adsorbate is directed to the condenser this is the desorption phase.

The following technical parameters of the device were designed:

- sorption column power: up to $200 \mathrm{~W}$ per 1 meter of pipe in the adsorber/desorber,

- length of adsorber/desorber column: $1.0 \mathrm{~m}$,

- diameter of the pipe inside adsorber/desorber: $\mathrm{Cu} 22 \times 1 \mathrm{~mm}$,

- coating of the pipes inside adsorber: stainless steel $103 \times 1,5$ $\mathrm{mm}$,

- silica gel layer thickness: $15 \mathrm{~mm}$,

- mass of the silica gel in the sorption column: $1.05 \mathrm{~kg}$

- max. power of evaporator (3 working sorption columns): $800 \mathrm{~W}$,

- max. power of condenser (3 working sorption columns): $600 \mathrm{~W}$,

- temperature of cooling water in adsorption: $30^{\circ} \mathrm{C}-45^{\circ} \mathrm{C}$,

- water mass flow of cooling water in adsorption: $0.06 \mathrm{~m}^{3} / \mathrm{h}-0.23 \mathrm{~m}^{3} / \mathrm{h}$,

- pressure drop of cooling water in adsorption: $1.5 \mathrm{kPa}-25 \mathrm{kPa}$

- temperature of heating water in desorption: $60^{\circ} \mathrm{C}-95^{\circ} \mathrm{C}$,

- water mass flow of heating water in desorption: $0.06 \mathrm{~m}^{3} / \mathrm{h}-0.23 \mathrm{~m}^{3} / \mathrm{h}$,

- pressure drop of heating water in desorption: $1.5 \mathrm{kPa}-25 \mathrm{kPa}$,
- temperature of cooling water in condenser: $35^{\circ} \mathrm{C}-50^{\circ} \mathrm{C}$,

- water mass flow of cooling water in condenser: $0.08 \mathrm{~m}^{3} / \mathrm{h}-0.35 \mathrm{~m}^{3} / \mathrm{h}$,

- pressure drop of cooling water in adsorption: $2.5 \mathrm{kPa}-30 \mathrm{kPa}$

- temperature of chilled water in evaporator: $5^{\circ} \mathrm{C}-25^{\circ} \mathrm{C}$,

- water mass flow of chilled water in evaporator: $0.08 \mathrm{~m}^{3} / \mathrm{h}$ $0.35 \mathrm{~m}^{3} / \mathrm{h}$,

- pressure drop of chilled water in evaporator: $2.5 \mathrm{kPa}-30 \mathrm{kPa}$.

\subsection{Design and realization of the adsorption/desorption process}

Through the use of a sequential system of sorption columns work, the continuous character of the gained power of the device in a wide range is obtained.

It is assumed that the full cycle of the process is divided into sub-phases, the number of which is equal to the number of operating adsorption columns. After completion of the partial subphase in the last column the heat pump begins first partial phase, and thus starts the next full cycle of its operation (Fig. 2). Operating sub-phases of the sorption columns of the six-bed adsorption heat pump in the serial-serial mode, always assuming that three columns participate in the adsorption process and three columns participate in the desorption process ( 3 columns for adsorption / 3 columns for desorption).

In the Fig. 1, adsorption heat pump during the zero phase of the cycle, regarding the external refrigerant circuit is presented. The cooling water from the supply distributor is directed to the first sorption column carrying out the adsorption process. Then after receiving the heat resulting the adsorption, it leaves it and flows into subsequent adsorption columns in series. Since the cooling water warmed up initially during its passage through the column 1 and 2 , therefore, the adsorption process in the $3^{\text {rd }}$ column is slower. Cooling water, after flowing through three columns, supplies flow distributor and is intended for further use. After the adsorption process $1^{\text {st }}$ column is switched to desorption 
process and is supplied with heating water (driving heat) during the next phase of the cycle.

Similar to the previous process, the desorption column is supplied with heating water from distributor. The high temperature heating water is directed to column 4 and then flows through column 5 and 6 after which it is directed to the heating water return distributor. As a result of desorption heating water is cooled down. During desorption the refrigerant is desorbed very quickly in the first column, thus this column is assigned to the adsorber process and is supplied with water as the last one in series during the next cycle.

In the next phase of the cycle, columns 2, 3 and 4 participate in the adsorption process, however, it is column number 2 supplied with cooling water from the water distributor as the first in series to obtain the highest possible concentration of vapour (uptake) in the sorption bed. In columns 3 and 4 the adsorption process is being continued. Analogously, columns 5, 6 and 1 participate in the desorption process, however column 5 is supplied with heating water from the distributor as first in order. For the considered adsorption heat pump, regardless of the phase in progress, the assumption that three columns participate in the adsorption process and three columns participate in the desorption process is always accepted.

Conducting subsequent cycles of the heat pump operation allows to obtain the assumed saturation of the bed, required concentration or to obtain the assumed temperature of the utilized water as a medium.

Through the use of a sequential system of sorption columns, a continuous and adjustable character of the heating/cooling power in a wide range is obtained. It is possible as a result of using in the device the quantitative control of the pump by switching sequential columns (step control), quality control by changing the temperature of heating/cooling water flowing in series or parallel through sorption columns and by changing the time parameter of sorption process (adsorption/desorption time) of the bed. The described adjustment possibilities were obtained with the use of a control "multivalve" (Fig. 3). Its task is to perform the set algorithm of sequential operation of the multi-bed adsorption heat pump.

Designed multivalve, in general, is a set of valves with actuators for switching inflow/outflow of water from/to distributors and columns. This ensures the implementation of three major states of the multivalve in the adsorption heat pump:

a) water flow between the adsorption/desorption columns,

b) supply/return water to/from the column during adsorption,

c) supply/return water to/from the column during desorption.

Valves with actuators, controlling the flow of water ensure the supply of the heating/cooling medium at the assumed temperature level and thus allow the control of the sorption process in columns, either as adsorber or desorber. The operation of valves is coordinated with the valves that open access to the evaporator or condenser. Sorption column operating as adsorber is connected to the evaporator and the column operating as desorber is connected to the condenser. The circulation of the working vapour (adsorbate) remains the same as in regular two-bed adsorption heat pump.

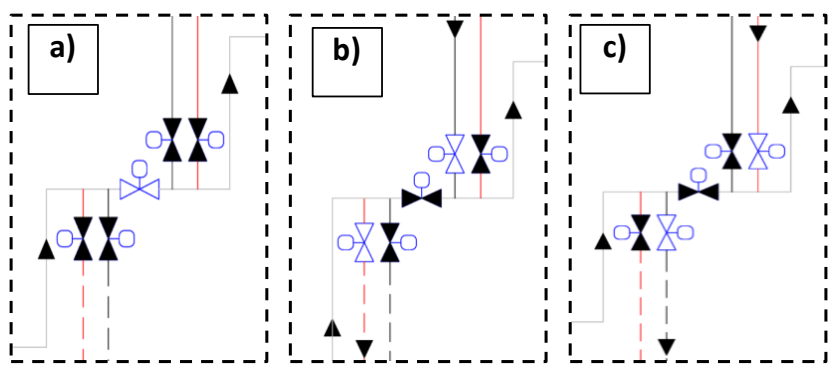

Fig. 3. Major states of the multivalve: a) water flow between the bed, b) supply/return water to/from the bed during adsorption, c) supply/return water to/from the bed during the desorption

\section{Automatic control system of single-stage six-bed adsorption heat pump}

\subsection{Requirements analysis}

The selected task of the control system is to automatically control the temperature of the utility medium in the adsorption heat pump by switching on the solenoid valve sections that change the directions of vapour and water flow.

Based on the initial assumptions, the following system functions were determined:

- Checking the pre-conditions necessary for the correct operation of the device;

- measuring the temperature of water and vapour at specific points of the installation;

- measurement of water pressure and vapour at certain points of the installation;

- measurement of water and vapour flow at specific points of the installation.

- controlling the direction of water and vapour;

- communication with the operator - manual or e.g. heating curve setting temperature;

- signalling of process states and alarms.

The diagram illustrating the individual functions of the device is shown in Figure 4.

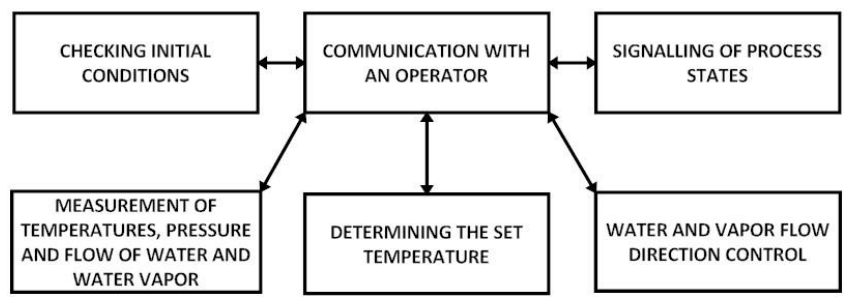

Fig. 4. Functional structure of the adsorption heat pump control system

Detailed functions of the control system:

1. System activation - the conditions for activation are:

- properly functioning control system (presence of power supply, controller in run mode, program in the controller running),

- an emergency switch not active,

- adequate vacuum (vacuum),

- specific water flow through the evaporator and condenser,

- specific vapour flow from the evaporator to the sorption chamber.

2. Temperature, pressure and flow measurement:

- it must be done by a device independent of the controller,

- the device must support signal variability ranges, in accordance with Table 1 ,

- detailed requirements for measuring devices are set out in Table 1,

- supply voltage for the measuring devices - 24 VDC.

3. Communication with the operator (operator's activities):

- system activation - active system (power supply for actuators, i.e. pump and valves),

- switching on the control - starts controlling the directions of water and vapour flows,

- alarms clearing - a continuation of the control,

- emergency stop - stopping the control by means of the emergency stop switch, which should cut off the power supply to the controller outputs and the power supply to actuators, regardless of the controller.

4. Process status signalling

- system ready - waiting for the control to be turned on,

- system during work - control,

- alarm - control stopped - alarm occurs if :

- the permissible temperature for silica gel in the sorption chamber will be exceeded, 
- there will be no vapour flow - no proper vacuum pressure (vacuum pump not working, leakage, etc.)

the maximum heating water temperature is exceeded

- reporting alarm states of all measured variables, e.g. assumed VarHiHi values (maximum critical value of a specific variable), VarLoLo (minimum critical value of a specific variable), $\mathrm{VarHi}$ (max allowable value of a specific variable), VarLo (min allowable value of a specific variable).

5. Determining the set temperature of the utility medium

- manual entry of the set temperature value,

- setting the set temperature based on the heating curve,

6. Controlling the direction of flow of water and vapour

- controlling the number of adsorbers working in series (from 1 to 3) by opening the vapour supply valve of the switched device and opening the bypass valve and closing the valves on the supply and return of the previous adsorber,

- after reaching the maximum number of adsorbers switched on, reducing the flow of the utility medium.

Table 1. Technical parameters of measuring devices

\begin{tabular}{|l|c|c|}
\hline Parameter & Symbol & Range \\
\hline Sensors of water parameters at the adsorbers & \\
\hline Water temperature & TT1-TT12 & $0-100^{\circ} \mathrm{C}$ \\
\hline Water pressure & PT1-PT12 & $0-40 \mathrm{kPa}$ \\
\hline Flow & FT1-FT6 & $0-0.21$ \\
\hline Sensors of vapour parameters at adsorbers, evaporator and condenser \\
\hline Vapour temperature & TT13 - TT20 & $0-100^{\circ} \mathrm{C}$ \\
\hline Vapour pressure & PT13 - PT20 & $0-40 \mathrm{kPa}$ \\
\hline Flow & FT7 & $0-1 \mathrm{~m}^{3} / \mathrm{h}$ \\
\hline Flow & FT8 & $0-6 \mathrm{~m}^{3} / \mathrm{h}$ \\
\hline Sensors of water supplying to adsorbers & \\
\hline Water temperature & TT21-TT24 & $0-100^{\circ} \mathrm{C}$ \\
\hline Water pressure & PT21 - PT24 & $0-40 \mathrm{kPa}$ \\
\hline Water flow & FT9-FT10 & $0-0.81 / \mathrm{s}$ \\
\hline Sensors for evaporator and condenser feed water parameters \\
\hline Water temperature & TT25 - TT28 & $0-100^{\circ} \mathrm{C}$ \\
\hline Water pressure & PT25 - PT28 & $0-40 \mathrm{kPa}$ \\
\hline Water flow & FT11 - FT12 & $0-0.81 / \mathrm{s}$ \\
\hline Condensate parameters sensors (returning to the evaporator) \\
\hline Flow & FT13 & $0-21 / \mathrm{s}$ \\
\hline
\end{tabular}

\subsection{Functional modules of the control system}

Based on requirements analysis the control system can be divided into a number of separate, functionally dependent components, shown in Figure 5:

- control system,

- activation system,

- water and vapour temperature measurement systems,

- water and vapour pressure measurement systems,

- water and vapour flow measurement systems,

- solenoid valves sequential activation system,

- operator panel,

- supply system.

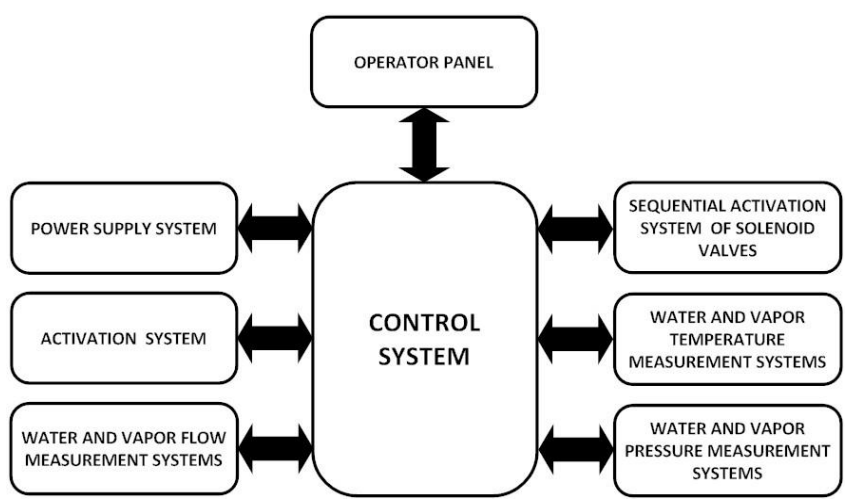

Fig. 5. Functional modules of the adsorption heat pump control system

Control system - the construction is based on the programmable controller, which will be used as an executive platform for control algorithms. After adding up all the inputs and outputs of individual system components, it turned out that the controller must have at least 10 binary inputs, at least 42 binary outputs and at least 69 analogue inputs. Due to the type of switched signals, the binary outputs are to be of transistor/relay type. Due to the possibility of interference with analogue signals and the length of the cabling, a 4-20 [mA] current standard should be used.

Activation system - turns on the power of actuators only after the full start of the controller and constantly checks whether adequate vacuum is provided, whether there is the required water flow through the evaporator and the condenser, whether there is the required vapour flow from the evaporator to the sorption chamber, disconnects the power supply and sends information about it to the control system. The system consists of: two-state sensors for vacuum, vapour and water flow, emergency stop switch and toggle switch. We describe below specific functions of all inputs and outputs in accordance with the variable type in the control program.

Outputs:

$\begin{array}{ll}\text { - } \quad \text { "Active system" light } & -1 \mathrm{bit} \\ \text { - } \quad \text { "Controller ready" light } & -1 \mathrm{bit} \\ \text { Inputs: } & \\ \text { - } \quad \text { switch (key) "Activate system" } & -1 \mathrm{bit} \\ \text { - } \quad \text { "Negative pressure OK" sensor } & -1 \mathrm{bit} \\ \text { - } \quad \text { "OK vapour flow" sensor } & -1 \mathrm{bit} \\ \text { - } \quad \text { "Water flow OK" sensor } & -1 \mathrm{bit}\end{array}$

Solenoid valves sequential activation system its task is to sequentially switch on the appropriate solenoids, providing vapour and water flows in a given direction.

Outputs:

- solenoid valve control

vacuum pump control

$$
\begin{aligned}
& -42 \text { bits } \\
& -1 \text { bit }
\end{aligned}
$$

Temperature, pressure and flow measuring systems for water and vapour - are designed to read the current value of a specific parameter and send it to the control system as an electric signal, i.e. current. An arrangement of all analogue measuring devices is shown in Figure 6.

Inputs:

- information from sensors $\quad-69-16$ bits words

Operator panel - buttons and switches used to control the process and indicator lights informing about the status of the process. The following operations planned from the panel are planned:

- system activation - mode of operation, inputs and outputs, described in the section Activation system.

- switching on and stopping the control

Outputs:

$\begin{array}{ll}\text { - } \quad \text { "Active Control" light } & -1 \text { bit } \\ \text { Inputs: } & \\ \text { - } \quad \text { "Start" button } & -1 \text { bit } \\ \text { - } \quad \text { "Stop" button } & -1 \text { bit }\end{array}$

- Alarm clearing - after the alarm signal has been cleared, the control continues.

Outputs:

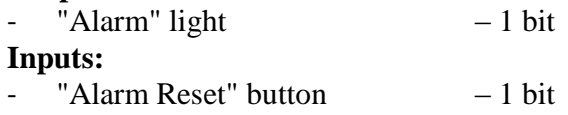

- Emergency stopping of the device - when any abnormal or dangerous situation occurs, an operator should immediately stop the heat pump.

Outputs:

$\begin{array}{ll}-\quad \text { "Failure" lamp } & -1 \text { bit } \\ \text { Inputs: } & \\ \text { - } \quad \text { "Emergency Stop" switch } & -1 \text { bit }\end{array}$

Power supply system - in the heat pump control system two separate supply systems will be used for the control system and external devices. Supply systems should provide standard 24VDC supply voltage for the control system and external devices sensors, solenoid valves and relays. 


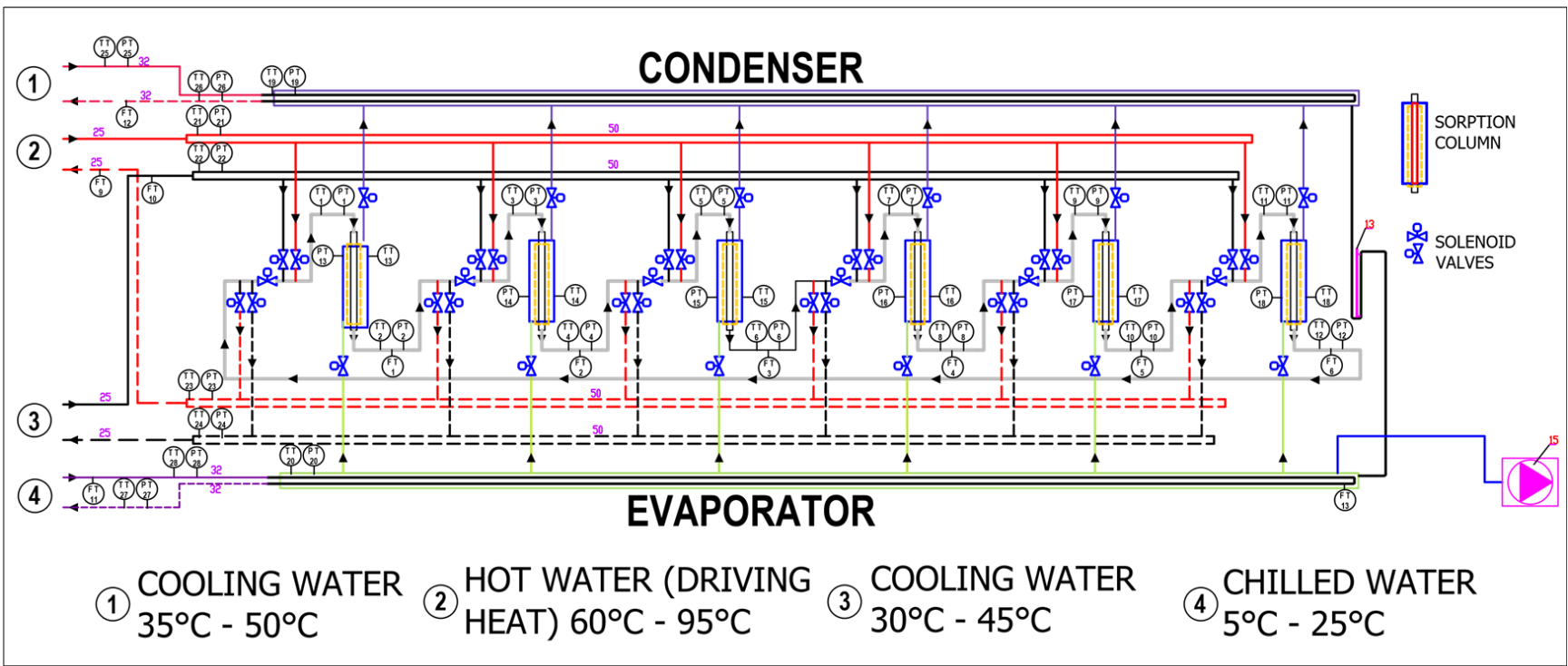

Fig. 6. Arrangement of analogue measuring devices for the six-bed adsorption heat pump

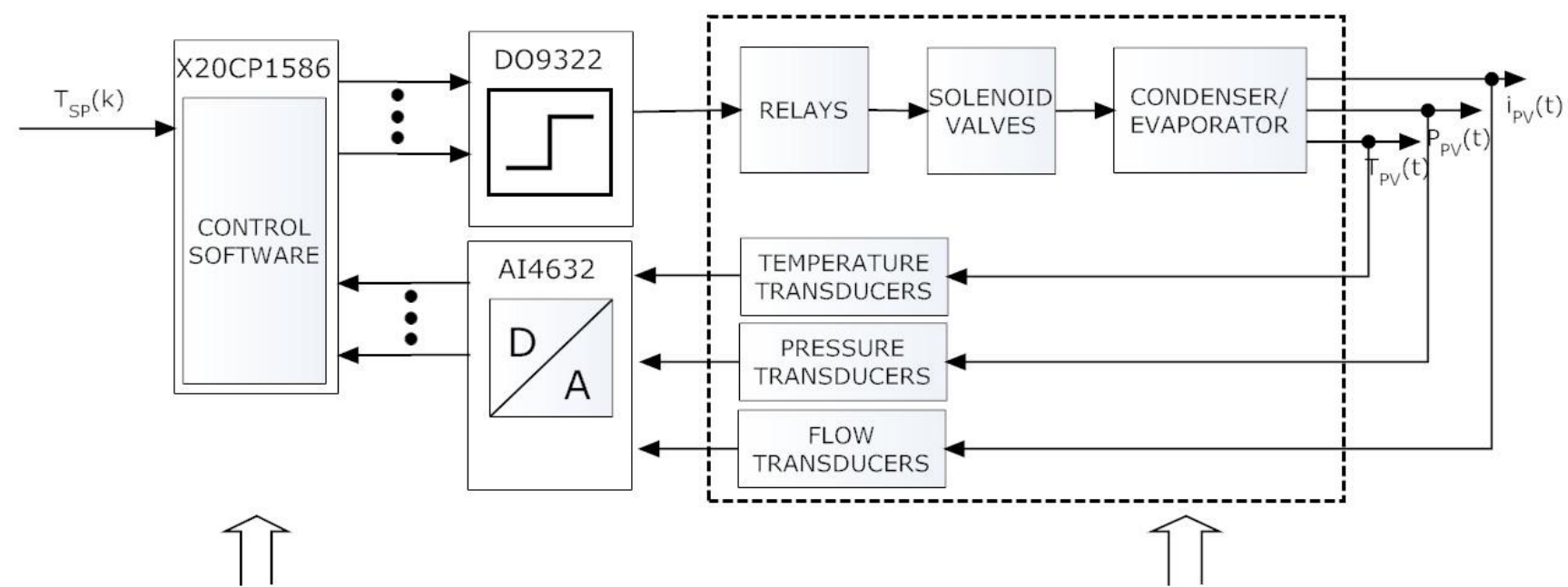

CONTROL DEVICE

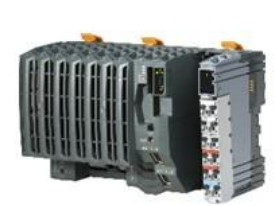

B\&R PROGRAMMABLE CONTROLLER X20CP1586

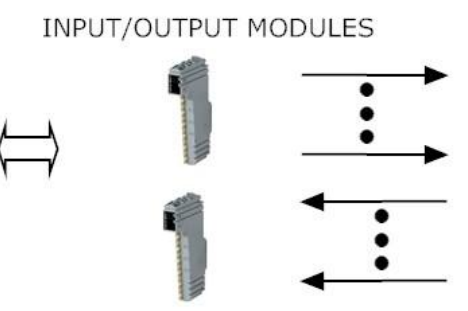

B\&R EXPANSION MODULES AI4632 AND D09322

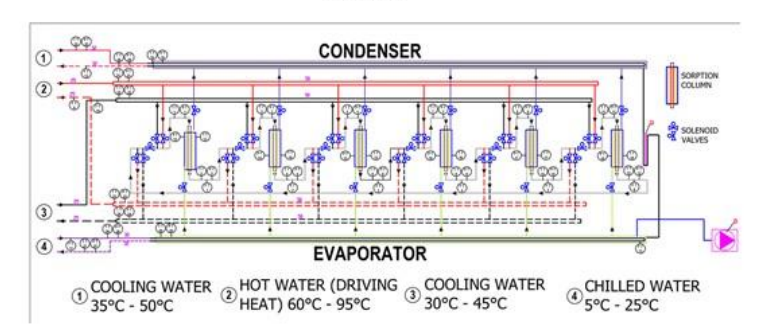

HEAT PUMP

Fig. 7. General diagram of the adsorption heat pump control system

\subsection{Hardware configuration of the control system}

A general diagram of the heat pump control system is presented in Figure 7. The main part of the control system is the control device (X20CP1586), which is a programmable digital controller, typically used in industrial automation systems. A control device cooperates with the plant by means of input/output devices i.e. analogue/digital inputs and digital inputs/outputs.
The main task of the control system is to make a temperature $T_{P V}(t)$ stable and close as possible to the set temperature $T_{S P}(t)$.

By means of analogue/digital modules (AI4632) are proceeded signals from temperature, pressure and flow transducers. Based on these measurements and sequential procedure, described earlier, the programmable controller X20 CP1586 activates solenoid valves by means of digital output modules (DO9322) to achieve set temperature $T_{S P}(t)$ of the utility medium. A crucial for proper control operations is developed sequential control algorithm. 


\section{Conclusion}

Through the use of a sequential system of sorption columns operation, the continuous character of the gained power of the device in a wide range is obtained. It is possible as a result of using in the device the quantitative control of the pump by switching sequential columns (sequential control), quality control by changing the temperature of heating/cooling water flowing in series or parallel through sorption columns and by changing the time parameter of sorption process (adsorption/desorption time) of the bed. The described control possibilities were obtained by using of a "multivalve" control, which task is to perform a given algorithm for sequential heat pump operation.

The described nature of the operation of a multi-bed heat pump refers to a system in which the heating/cooling water flows through the sorption columns in series mode, and the number of columns assigned for adsorption or desorption is half of the total number of columns in the device. However, the presented method of control enables the device to be launched in accordance with other systems. For example, in one of them, the number of sorption columns assigned to the adsorption/desorption process may be asymmetric (more for adsorption due to the slower course of this process). The next system is one in which the heating/cooling medium flows through the sorption columns in parallel (to each column directly from the distributor). The additional variance is a system in which, through the adsorbent beds the cooling medium flows, for example, in series, and through the desorption column, in parallel.

The heat pump control system presented in the last part of the article enables flexible automatic temperature control. But this requires multi-point measurement of temperature, pressure and flow of both water and vapour. Apart from measurement part, a sequencer control algorithm is needed for the proper solenoid valves manipulations.

\section{References}

[1] Akisawa A., Miyazaki T.: Mutli-bed adsorption heat pump cycles and their optimal operation. In: Saha B.B., Ng K. C. (Ed.): Advances in Adsorption Technology. Nova Science Publishers, 2010

[2] Badura J., Wiśniewski A.: Dociążenie obiegu energetycznego elektrociepłowni z wykorzystaniem urządzeń chłodniczych i pomp ciepła. In: Trela M. (Ed.): Ciepło skojarzone: komfort zima i latem - trójgeneracja : materiały $\mathrm{z}$ konferencji naukowo-technicznej, Wydawnictwo Instytutu Maszyn Przepływowych, Gdańsk 2005.

[3] Chua H. T., Ng K. C., Malek A., Kashiwagi T., Akisawa A., Saha B. B.: Multibed regenerative adsorption chiller - improving the utilization of waste heat and reducing the chilled water outlet temperature fluctuation. International Journal of Refrigeration 24(2), 2001, 124-136.

[4] Demira H., Mobedi M., Ülkü S.: A review on adsorption heat pump: Problems and solutions. Renewable and Sustainable Energy Reviews 12, 2008, 23812403.

[5] Fan Y., Luo L., Souyri B. B.: Review of solar sorption refrigeration technologies: Development and applications. Renew. Suist. Energy Rev 11(8), 2007, 1758-1775

[6] Grisel R. J. H, Smeding S. F., De Boer R.: Waste heat driven silica gel/water adsorption cooling in trigeneration. Applied Thermal Engineering 30, 2010, 1039-1046.

[7] Grzebielec A.: Zastosowanie i perspektywy rozwoju adsorpcyjnych urządzeń chłodniczych w chłodnictwie i klimatyzacji. Chłodnictwo i Klimatyzacja 4, 2005, 52-57.

[8] Gwadera, M., Kupiec, K.: Adsorpcyjne układy chłodnicze. Inż. Ap. Chem. 50(5), 2011, 38-39.

[9] Idczak M.: Współczesne technologie wykorzystania ciepła do produkcji chłodu małej wydajności. Workshop: Wykorzystanie ciepła sieciowego do produkcji chłodu, sposobem na zwiększenie efektywności systemów ciepłowniczych, Warszawa 2008

[10] Jaskólski M.: Adsorpcyjne układy klimatyzacyjne. In: Trela M. (Ed.): Ciepło skojarzone: komfort zimą i latem - trójgeneracja : materiały z konferencji naukowo-technicznej, Wydawnictwo Instytutu Maszyn Przepływowych, Gdańsk 2005.

[11] Meunier F.: Solid sorption heat powered cycles for cooling and heat pumping applications. Applied Thermal Engineering 18, 1998, 715-729.

[12] Nunez T., Mittelbach W., Henning H. M.: Development of an adsorption chiller and heat pump for domestic heating and air-conditioning applications. Appl Therm Eng 27(13), 2007, 2205-12.

[13] Paderewski M. L.: Procesy adsorpcyjne w inżynierii chemicznej. Wydawnictwa Naukowo-Techniczne, Warszawa 1999.

[14] Park I., Knaebel K. S.: Adsorption breakthrough behavior: unusual effects and possible causes. AIChE Journal 38(5), 1992, 660-670.

[15] Rosiński M.: Odzyskiwanie ciepła w wybranych technologiach inżynieri środowiska. Oficyna Wydawnicza Politechniki Warszawskiej, Warszawa 2008.

[16] San J-Y, Hsu H-Ch.: Performance of a multi-bed adsorption heat pump using SWS-1L composite adsorbent and water as the working pair. Appl Therm Eng, 29(8-9), 2009, 1606-1613.

[17] Srivastava N. C., Eames I. W.: A review of developments in solid-vapour adsorption refrigeration and heat pump systems. Journal of the Institute of Energy 70, 1997, 116-127.

[18] Wang A., Chua H. T., Ng K. C.: Experimental investigation of silica gel-water adsorption chillers with and without a passive heat recovery scheme. International Journal of Refrigeration 28(5), 2005, 756-765.

[19] Yildirim Z. E, Mobedi M., Ulku S.: A Review on proper working pairs for solar adsorption heat pumps. Proceedings Book: Solar Future, 2010.

[20] Zarzycki R.: Wymiana ciepła $\mathrm{i}$ ruch masy $\mathrm{w}$ inżynierii środowiska. Wydawnictwa Naukowo-Techniczne, Warszawa 2010

[21] Zwarycz-Makles K., Kuczynski K.: Model and simulation of six-bed silica gelwater adsorption heat pump. In: Stanek W., Gładysz P. et al. (Ed.): $4^{\text {th }}$ International Conference on Contemporary Problems of Thermal Engineering. The Silesian University of Technology, Institute of Thermal Technology, Gliwice-Katowice 2016, 809-818.

[22] Zwarycz-Makles K., Szaflik W., Kuczynski K., Nejranowski J.: Projekt sześciokomorowej adsorpcyjnej pompy ciepła i jej automatycznej regulacji. In: Besler M., Fijewski M. (Ed.): 2014 Air \& Heat Energy in Buildings. Oficyna Wydawnicza Politechniki Wrocławskiej, Wrocław 2014, 317-322.

\section{Ph.D. Eng. Katarzyna Zwarycz-Makles}

email: Katarzyna.Zwarycz-Makles@zut.edu.pl

M.Sc. Eng. graduate at Technical University of Szczecin in 2000, Faculty of Civil Engineering, field of study: Sanitary Devices. In 2002 UNU scholarship in Reykjavik in geothermal water utilization. Ph.D. defended in 2006 at Faculty of Mechanical Engineering, field of study: modelling of heat exchange in ground heat storage. 3 years of professional experience in designing of building installations and in the selling of ventilation devices. From 2008 assistant professor in Department of Heating, Ventilation and Heat Engineering. Manager of research project in 2011-2014. Research interests include renewable, alternative and conventional heat sources, external heating installations i.e. snow melting, mathematical modelling of heat transfer.

ORCID ID: 0000-0002-3738-9596

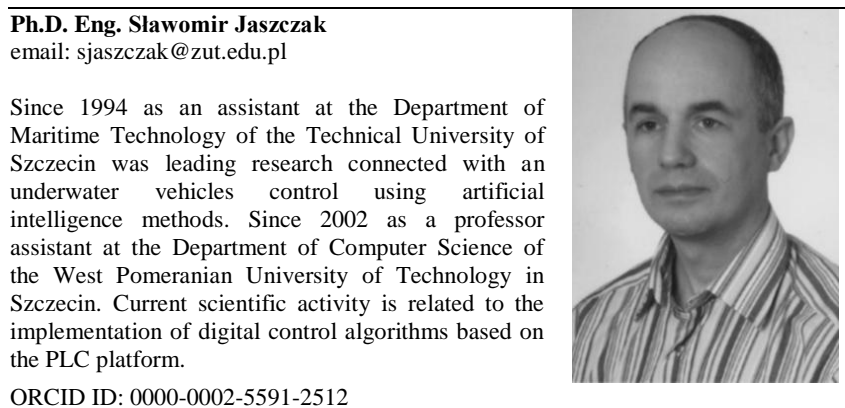

ORCID ID: 0000-0002-5591-2512

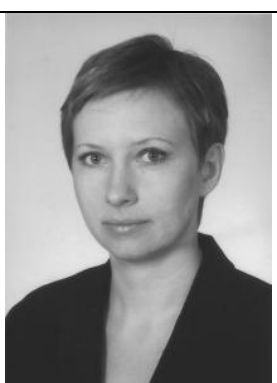

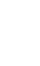

